\title{
Nutrient Release during Residue Decomposition of Weeds Mown at Different Times in a Persimmon Orchard
}

\author{
Seong-Tae Choi*, Seong-Cheol Kim, Gwang-Hwan Ahn, Doo-Sang Park, Eun-Seok Kim \\ Sweet Persimmon Research Institute, Gyeongsangnam-do Agricultural Research and Extension Services, Gimhae, Korea \\ Email: *stchoi1234@korea.kr
}

How to cite this paper: Choi, S.-T., Kim, S.-C., Ahn, G.-H., Park, D.-S. and Kim, E.-S. (2017) Nutrient Release during Residue Decomposition of Weeds Mown at Different Times in a Persimmon Orchard. Journal of Agricultural Chemistry and Environment, 6, 153-164.

https://doi.org/10.4236/jacen.2017.64010

Received: August 28, 2017

Accepted: October 9, 2017

Published: October 12, 2017

Copyright $\odot 2017$ by authors and Scientific Research Publishing Inc. This work is licensed under the Creative Commons Attribution International License (CC BY 4.0).

http://creativecommons.org/licenses/by/4.0/

\begin{abstract}
Decomposition and nutrient release of the residue subsequent to mowing weeds remain poorly understood in persimmon orchards of South Korea. The litterbags including various weed residues were deposited on the soil surface under the tree canopy to simulate the fate of weeds mowed on $13 \mathrm{May}, 13 \mathrm{Ju}-$ ly, and 13 September 2011 and 2012. Rate of decomposition and nutrient release of the residues depended on different mowing times. Residual dry mass (DM) of the 13 May weeds decreased by $17 \%-21 \%$ of initial DM during 1 month and by $63 \%$ - 71\% until 2 months after litterbag deposition, and they released $51 \%$ - $67 \%$ of nitrogen $(\mathrm{N}), 54 \%$ - $55 \%$ of phosphorus $(\mathrm{P})$, and $92 \%-94 \%$ of potassium $(\mathrm{K})$ of respective initial amount until the first 2 months. The 13 July weeds rapidly decomposed during the first month, accounting for $51 \%-64 \%$ of DM and released $49 \%-67 \%$ of N, $27 \%-54 \%$ of P, and $76 \%-77 \%$ of $\mathrm{K}$. When mowed on 13 September, the weed residue decomposed slower and longer than the 13 May and 13 July weeds, losing $48 \%-51 \%$ of DM, $36 \%-39 \%$ of N, $60 \%-64 \%$ of $\mathrm{P}$, and $70 \%-77 \%$ of $\mathrm{K}$ during the first 2 months but continuing an active decomposition even at 6 months after the deposition. The results indicated that time of supplemental fertilization should be adjusted depending on mowing times, and the mowing times be controlled to meet seasonal demand of persimmon trees for nutrients.
\end{abstract}

\section{Keywords}

Persimmon, Mowing, Weed Decomposition, Nutrient Release, Sod Culture

\section{Introduction}

Floors of persimmon orchards in South Korea are managed in general with 
growing various weeds which are periodically mowed or sprayed with herbicides to prevent their excessive growth. The weeds have been used as one of the most important sources to improve the organic matter supply into the soil of the orchards. When the weeds were mowed in an orchard throughout a year, DM produced per ha reached to 15 ton but they compete with crops for nutrients from the soil [1]. Weeds can take up $232 \mathrm{~kg} \mathrm{~N}, 42 \mathrm{~kg} \mathrm{P}$, and $267 \mathrm{~kg} \mathrm{~K}$ per ha during the year in pear orchard of South Korea [1]. Once the residues from cover crops are deposited on the soil surface, inorganic nutrients contained in the residues are released to the soil throughout the decomposition, increasing their availability, and they may be taken up by succeeding crops [2] [3]. Therefore, cycle of nutrients after mowing weeds can play an important role for nutrient supply to maintain productivity of persimmon trees.

In sod culture using legumes and gramineous cover crops, the effectiveness of released nutrients and fertilizer value of the sods are affected by the rates of decomposition and nutrient release from the residues [4] [5]. The residue decomposition and nutrient release are dependent on residue quality and quantity, moisture and temperature, and specific soil factors such as texture, mineralogy and acidity, microbial activity, and the presence of other nutrients [5] [6] [7] [8]. Therefore, pattern of residue decomposition can also be changed depending on whether placing the residues on the soil surface or incorporated them into the soil. Several studies have shown that burying the residues into the soil accelerate decomposition more than placing on the soil surface, by exposing a larger surface area to microbial activity [2] [9] [10].

In hairy vetch, most nutrients in the residues may be released in the first 30 days after the residue deposition on the soil surface [6] [9]. However, the nutrient release is negatively correlated with carbon-to-nitrogen $(\mathrm{C} / \mathrm{N})$ ratio [11]. Lupwayi et al. (2004) found that under conventional tillage clover released up to $70 \%$ of the residue $\mathrm{P}$ after 12 months [12]. In Nordic conditions, $80 \%$ of $\mathrm{P}$ and $89 \%$ of $\mathrm{K}$ was released from legume shoot residue in 6 months after soil incorporation [3].

In Korean persimmon orchards located at slopes and rugged lands covered with naturally growing weeds, the decomposition of weed biomass and the nutrient release remain poorly understood. The weeds consist of various species depending on different orchards and seasons, and they are mown or sprayed with herbicides 2 to 5 times a year. It is supposed that patterns of the decomposition and nutrient release of the weed residues would be widely varied due to different weed species and mowing times, affecting nutrient uptake of the trees. The objective of this study was to determine the residue decomposition and the nutrient release in fields grown with persimmon trees.

\section{Materials and Methods}

\subsection{Experimental Site}

The experiment was conducted at Sweet Persimmon Research Institute $\left(35^{\circ} 16^{\prime} \mathrm{N}\right.$; $\left.128^{\circ} 43^{\prime} \mathrm{E}\right)$, Gimhae, southern area of South Korea. The experimental orchard was 
established in 1995 using "Fuyu" persimmon (Diospyros kaki). The trees were planted at a density of $6 \times 6 \mathrm{~m}$ and trained to open-center form. The rainfall and temperature data during the experiment were obtained from automatic weather station located at the Research Institute. Annual rainfall averaged $1465 \mathrm{~mm}$ in 2011, $1603 \mathrm{~mm}$ in 2012, and $1061 \mathrm{~mm}$ in 2013, and annual mean temperature was $12.8^{\circ} \mathrm{C}, 12.7^{\circ} \mathrm{C}$, and $13.5^{\circ} \mathrm{C}$ in the respective year (Figure 1). Soil type of the orchard was sandy-loamy Hydragric Anthrosols. In the $0-20 \mathrm{~cm}$ layer on 12 May 2011 before starting the experiment, the soil contained $7.7 \mathrm{~g} \cdot \mathrm{kg}^{-1}$ of organic matter, $\mathrm{pH}$ in water of $6.7,0.33 \mathrm{mg} \cdot \mathrm{kg}^{-1}$ of total $\mathrm{N}$ (Kjeldahl), $77 \mathrm{mg} \cdot \mathrm{kg}^{-1}$ of available $\mathrm{P}$, and $0.52 \mathrm{cmol}_{\mathrm{c}} \cdot \mathrm{kg}^{-1}$ of exchangeable K. Drip emitters delivered underground water to the trees 2 to 6 days per month depending on the needs of trees throughout the growing season.

\subsection{Litterbag Deposition}

The litterbag deposition, as described in previous studies [2] [3] [9], was designed for simulating the fate of weeds mowed at three different times, on 13 May, 13 July, and 13 September 2011 and 2012. The mowing dates were chosen to be similar to general mowing times in most persimmon orchards. The weeds were mowed at $3 \mathrm{~cm}$ level above the ground to be used as samples. The weed species at each mowing times are similar between the both years. Percent range of dominant weeds was approximately calculated by weighing each one from fresh samples of $2 \mathrm{~kg}$. The weeds on 13 May contained 25\% - 30\% quackgrass (Agropyron tsukusinense var. transiens), 15\% - 20\% pigeonvetch (Vicia hirsuta), and $15 \%-20 \%$ field horsetail (Equisetum arvense); on 13 July, 50\% - 60\% southern crabgrass (Digitaria ciliaris) and 10\% - 15\% green foxtail (Setaria viridis); on September 13, southern crabgrass $65 \%-70 \%$ (Digitaria ciliaris) and green foxtail 10\% - 15\% (Setaria viridis) (Table 1).

After being chopped to about $10-\mathrm{cm}$ length and mixed, fresh weights of weeds for adding to each litterbag were measured and labeled the bags. Weight of the

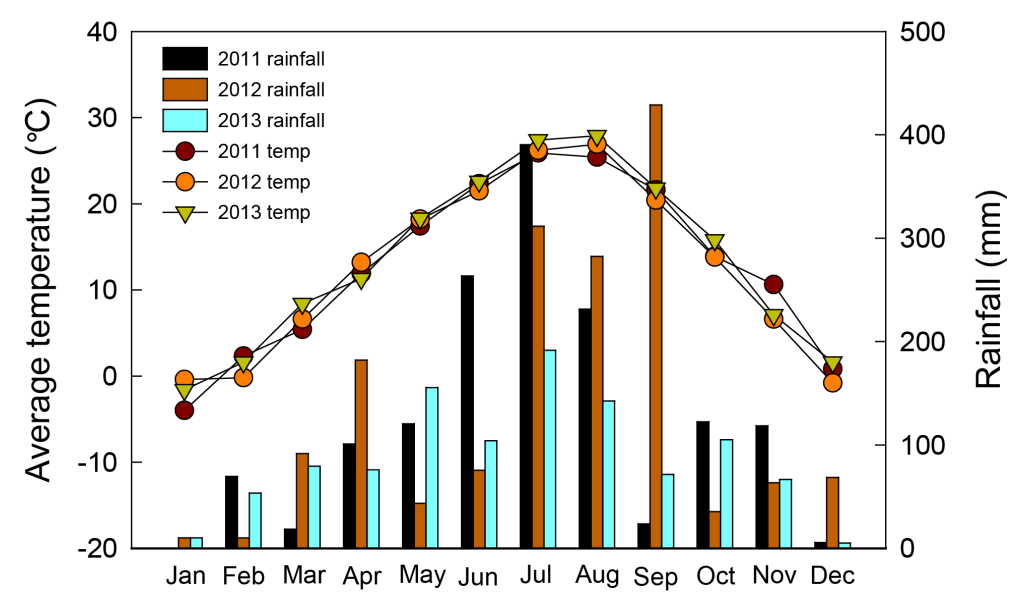

Figure 1. Monthly average temperature and rainfall during the experiment in a persimmon orchard. 
Table 1. C/N ratio and nutrient concentrations in dry matter of weeds ${ }^{\mathrm{a}}$ mowed under tree canopy of a persimmon orchard on 13 May, 13 July, and 13 September 2011 and 2012.

\begin{tabular}{cccccc}
\hline \multicolumn{2}{c}{ Mowing time } & C/N ratio & $\mathrm{N}$ & $\mathrm{P}$ & $\mathrm{K}$ \\
Year & Date & & & $(\% \mathrm{DW})$ & \\
2011 & 13 May & $15.3 \pm 0.6$ & 2.96 & 0.23 & 2.85 \\
& 13 July & $13.5 \pm 0.2$ & 2.50 & 0.34 & 4.46 \\
& 13 Sep. & $21.8 \pm 0.2$ & 1.50 & 0.24 & 2.43 \\
& 13 May & $14.5 \pm 0.2$ & 2.42 & 0.36 & 3.35 \\
& 13 July & $12.5 \pm 0.3$ & 2.70 & 0.41 & 5.77 \\
& 13 Sep. & $16.4 \pm 0.4$ & 1.73 & 0.36 & 3.85 \\
\hline
\end{tabular}

${ }^{\text {a}}$ Percent ranges of dominant weeds by fresh weight in both 2011 and 2012 were as follows: 13 May: quackgrass (Agropyron tsukusinense var. transiens) 25\% - 30\%, pigeon vetch (Vicia hirsuta) 15\% - 20\%, field horsetail (Equisetum arvense) 15\% - 20\%, and horseweed (Conyza canadensis) 10\% - 15\%. 13 July: southern crabgrass (Digitaria ciliaris) $50 \%-60 \%$, green foxtail (Setaria viridis) $10 \%-15 \%$, asiatic dayflower (Commelina commuis) 5\% - 10\%, and field horsetail (Equisetum arvense) 5\% - 8\%. 13 September: southern crabgrass (Digitaria ciliaris) 65\% - 70\%, green foxtail (Setaria viridis) 10\% - 15\%, field horsetail (Equisetum arvense) $7 \%-12 \%$, and asiatic dayflower (Commelina commuis) $5 \%-8 \%$.

weeds within a litterbag ranged from 350 to $400 \mathrm{~g}$. The litterbags were created with 60-mesh nylon fabric and dimensions of $50 \times 25 \mathrm{~cm}$. In addition, by weighing fresh and dry matter of some sample weeds, dry weight (DW) ratios were calculated to determine initial DW of weeds within each litterbag. The DM were weighed after drying at $80^{\circ} \mathrm{C}$ for $48 \mathrm{~h}$ and used to analyze $\mathrm{C} / \mathrm{N}$ ratio, $\mathrm{N}, \mathrm{P}$, and $\mathrm{K}$. By taking the concentrations of $\mathrm{N}, \mathrm{P}$, and $\mathrm{K}$ and the weed $\mathrm{DW}$, initial amount of the nutrients was calculated for all the litterbags at different mowing times.

The bags more than 12 per tree were deposited on the soil surface within 2-m periphery from the trunk under tree canopy on three mowing dates in both years. Three tree replications were imposed for the litterbag deposition of each mowing date. The bags were not contacted with drip emitters and fixed on the soil surface by iron bars to prevent possible movement caused by wind. Weeds grown from gaps between the bags were cut at $5-\mathrm{cm}$ level above the ground on the three mowing dates. To minimize external influence on the decomposition of weeds, compost or fertilizers was not supplied to the deposit sites during the experiment after the fist deposition on 13 May 2011. Pruned branches and fallen leaves from the persimmon trees were also removed from the site.

\subsection{Sampling and Measurement}

Three litterbags were sampled from the three deposit sites at one month interval from the deposition day until 13 November the mowing year and on 13 March, 13 June, or 13 September the next year. Soon afterwards, the residues were removed from litterbags and washed immediately with distilled water. Drying at $80^{\circ} \mathrm{C}$ to a constant weight, the residues were weighed to determine ratios of DM remained from decomposition of initial DM and used as sample to analyze $\mathrm{N}, \mathrm{P}$, 
and K. Dried samples were ground with a Wiley Mill (3383-L10, Thomas Scientific, Swedesboro, NJ, USA) to pass through a 20 -mesh screen. $\mathrm{C} / \mathrm{N}$ ratio was determined by dry combustion method on a CNS analyzer (Vario-Max, Elementar, Hanau, Germany). To determine total N, $0.2 \mathrm{~g}$ sub-samples were analyzed with a Kjeldahl instrument (Kjeltec 2300, Foss Co., Hgans, Sweden) by using the micro-Kjeldahl method [13]. $\mathrm{P}$ and $\mathrm{K}$ were analyzed by inductively coupled plasma emission spectrometer (ICPS-7510, Shimadzu Co., Tokyo, Japan) after digesting a $0.5 \mathrm{~g}$ sample with $\mathrm{HClO}_{4}$ and $\mathrm{H}_{2} \mathrm{SO}_{4}$ on a heating block according to the Methods for Chemical Analysis of Soils and Plants [14]. By taking the concentrations of $\mathrm{N}, \mathrm{P}$, and $\mathrm{K}$ and the weed $\mathrm{DW}$ on sampling date, ratios of the nutrients remained after releasing from initial contents in a litterbag were calculated.

\subsection{Data Analysis}

Means and SE values for weeds were calculated based on the data from 3 litterbags at each sampling time. The statistical software package SigmaPlot program (Version 8.0, SPSS Inc., USA) was used for data analysis.

\section{Results}

\subsection{Characteristics of Mowed Weeds}

Table 1 shows $\mathrm{C} / \mathrm{N}$ ratio and nutrient concentration of weed DMs before the litterbag decomposition on 13 May, 13 July, and 13 September 2011 and 2012. $\mathrm{C} / \mathrm{N}$ ratio ranged from 12.5 to 21.8 in both years, being the highest when weeds were mowed on 13 September. N concentration was at $2.42 \%-2.96 \%$ for 13 May and 13 July weeds but it decreased to $1.5 \%-1.73 \%$ for 13 September weeds. P ranged from $0.23 \%$ to $0.41 \%$ and $\mathrm{K}$ from $2.43 \%$ to $5.77 \%$, exhibiting no consistent changing of the concentration depending on the different mowing dates.

\subsection{Weeds Mowed on 13 May}

When litterbags including weeds were deposited on the soil surface after mowing them on 13 May, the residual DM within litterbag decomposed mostly until 2 months after the deposition (Figure 2). DM remaining (\% of initial DM) decreased by $17 \%-21 \%$ during the first month and by $63 \%-71 \%$ by 2 months, and then it gradually decreased by $79 \%$ by 6 months (13 November). $\mathrm{N}$ release from the residue followed pattern of DM decomposition, but it changed depending on the mowing years, being greater in 2012 than 2011 weeds. N remaining (\% of initial content) in the residues of both years decreased by $18 \%-28 \%$ during the first month and by $51 \%-67 \%$ after 2 months, and then by $70 \%-77 \%$ until 13 months (June 13 the next year). P of the residue did not easily release as fast as N. P remaining decreased by $67 \%-84 \%$ during the first three months and by $85 \%-93 \%$ until 13 months in both year weeds. The most rapidly released nutrient was $\mathrm{K}$ that released $29 \%$ of initial content during the first month but by 92\% - 94\% until 2 months. 

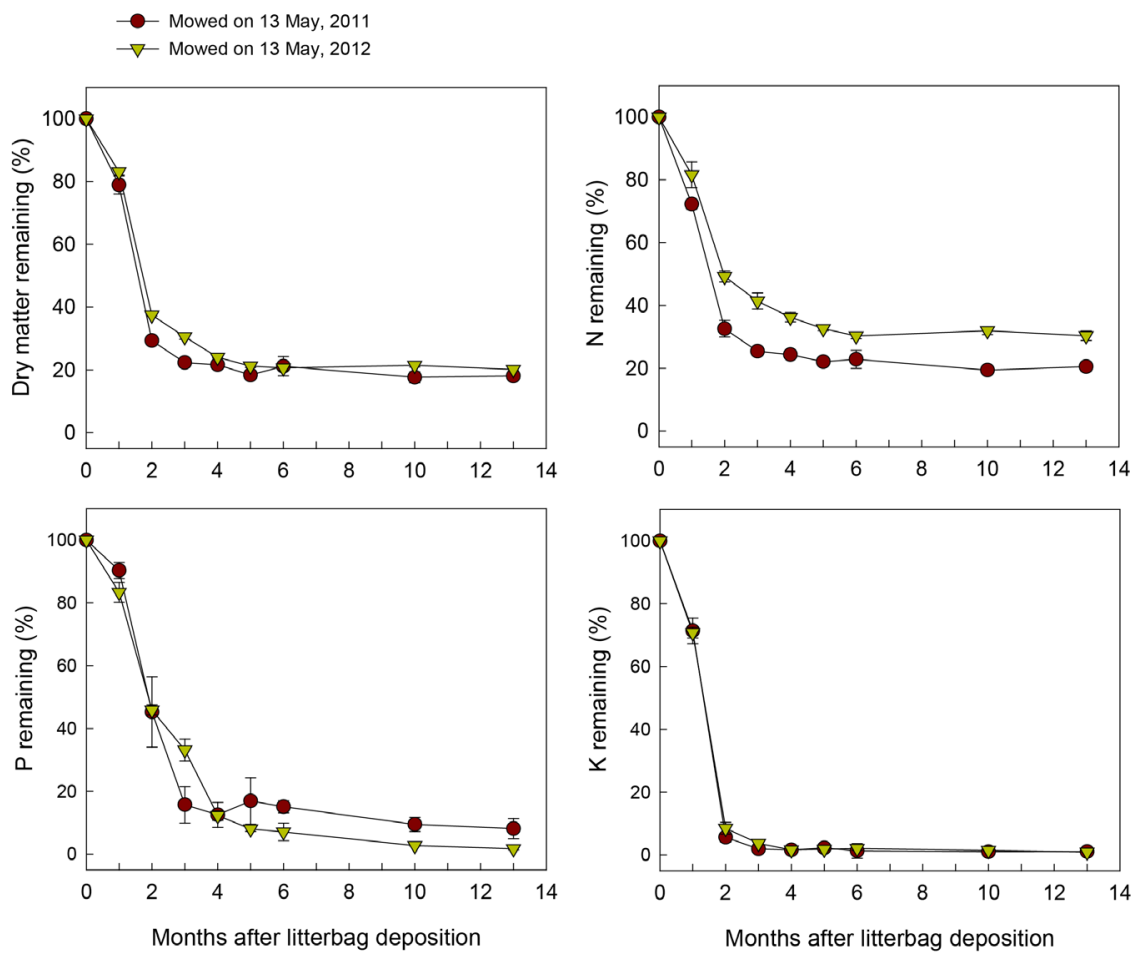

Figure 2. Dry matter (DM) and nutrient remaining (\% of initial content) in weed residues within litterbag deposited on the soil surface during the decomposition after mowing under tree canopy of a persimmon orchard on 13 May 2011 and 2012. Bars are standard error.

\subsection{Weeds Mowed on 13 July}

In litterbag deposited after 13 July mowing, decomposition of the residue differed from the 13 May weeds. During the first month, 51\% - 64\% of DM was lost (Figure 3). DM remaining decreased by $63 \%$ - $83 \%$ until 4 months and then stabilized, maintaining higher ratio in 2011 weeds. Release of $\mathrm{N}$ within litterbag followed DM decomposition as like in 13 May weeds; $\mathrm{N}$ remaining decreased by $49 \%-67 \%$ during the first month, and by $54 \%-73 \%$ until 2 months but the $\mathrm{N}$ release was not apparent after 4 months. Residual P gradually decreased by $72 \%$ - 90\% until 4 months, maintaining higher ratio in 2011 weeds. Among the nutrients, the most drastic release was observed in $\mathrm{K}, 76 \%-77 \%$ of which was released during the first month and 90\% - 99\% until 2 months.

\subsection{Weeds Mowed on 13 September}

After 13 September mowing, decomposition and nutrient release of the residue were slower and longer, compared with those of 13 May and 13 July weeds in both years (Figure 4). DM remaining decreased by 30\% - 37\% during the first month and by $48 \%$ - 51\% until 2 months after litterbag deposition. DM slowly decomposed in cold, dry season from 2 months (13 November) to 6 months (13 March), gradually decreasing by $74 \%-77 \%$ until 12 months (13 September the next year). The residue released $36 \%-39 \%$ of initial $\mathrm{N}$ until 2 months but after 

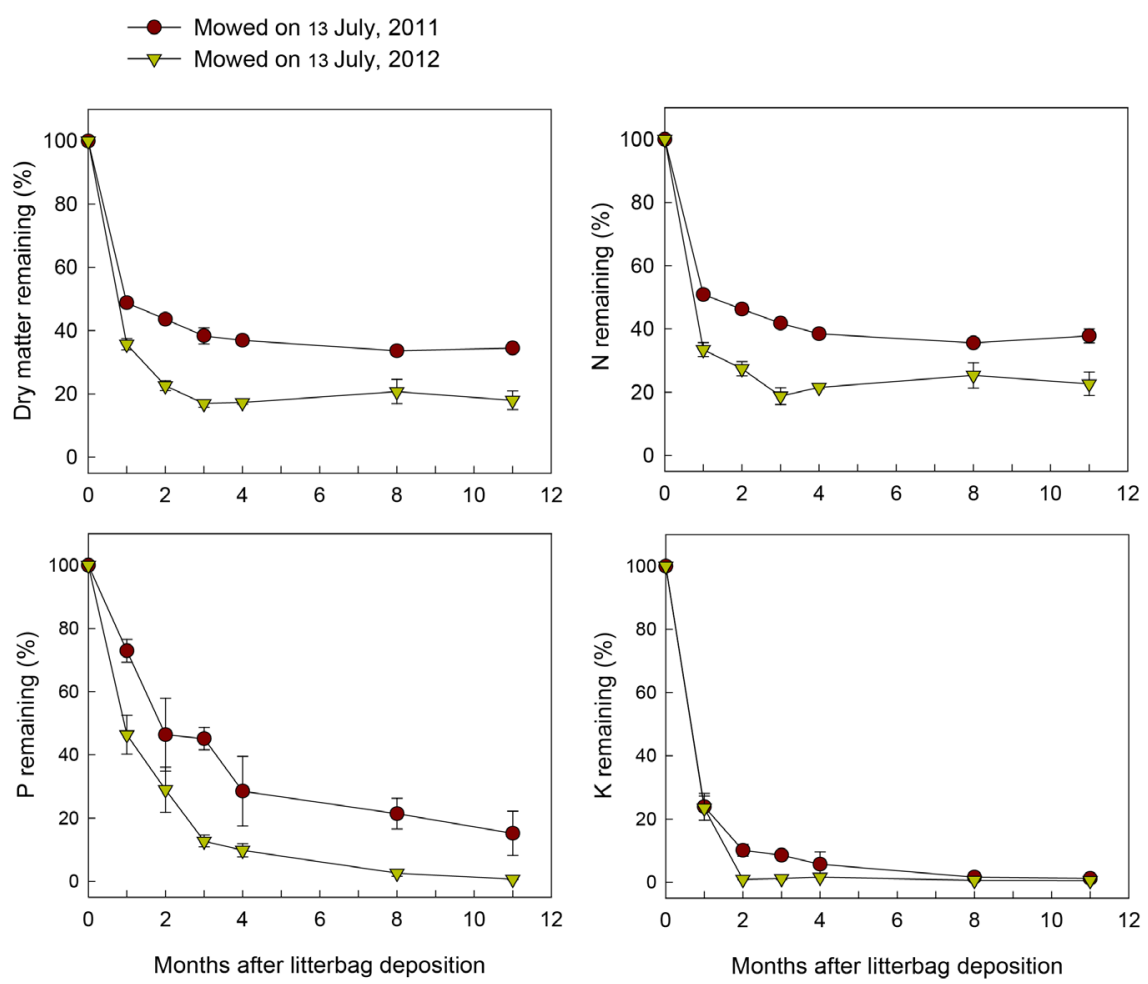

Figure 3. Dry matter (DM) and nutrient remaining (\% of initial content) in weed residues within litterbag deposited on the soil surface during the decomposition after mowing under tree canopy of a persimmon orchard on 13 July 2011 and 2012. Bars are standard error.

then the release become slow losing $62 \%-66 \%$ until 12 months. P was gradually released by $60 \%-64 \%$ during 2 month and by $98 \%$ until 12 months. The weed residue the most rapidly lost $\mathrm{K}$ among the nutrients just as in the May and July weeds, releasing $70 \%-77 \% \mathrm{~K}$ during 2 months after the deposition, and the release continued even in winter reaching at $91 \%-95 \%$ of initial content until 6 months.

\section{Discussion}

Although weed species were different on three mowing dates, DM loss was fastest near summer when temperature and rainfall were the highest in the year, while it became slow in spring or autumn. DM decomposition might have been promoted by rising air temperature and by rainfall in summer [6] [15] [16]. High temperature and rainfall affect microbial activity and the removal of soluble compounds, increasing decomposition and consequent reduction in residual DM [12] [17]. Due to lower temperature and lower water availability, September weeds slowly decomposed from 2 to 6 months after litterbag deposition. Likewise, greater decomposition of July weeds in 2012 than 2011 could be related in part to higher rainfall in September of 2012 (Figure 1). In addition, higher $\mathrm{C} / \mathrm{N}$ ratio of September weeds (Table 1) might also delay the decomposition [11] [18]. 

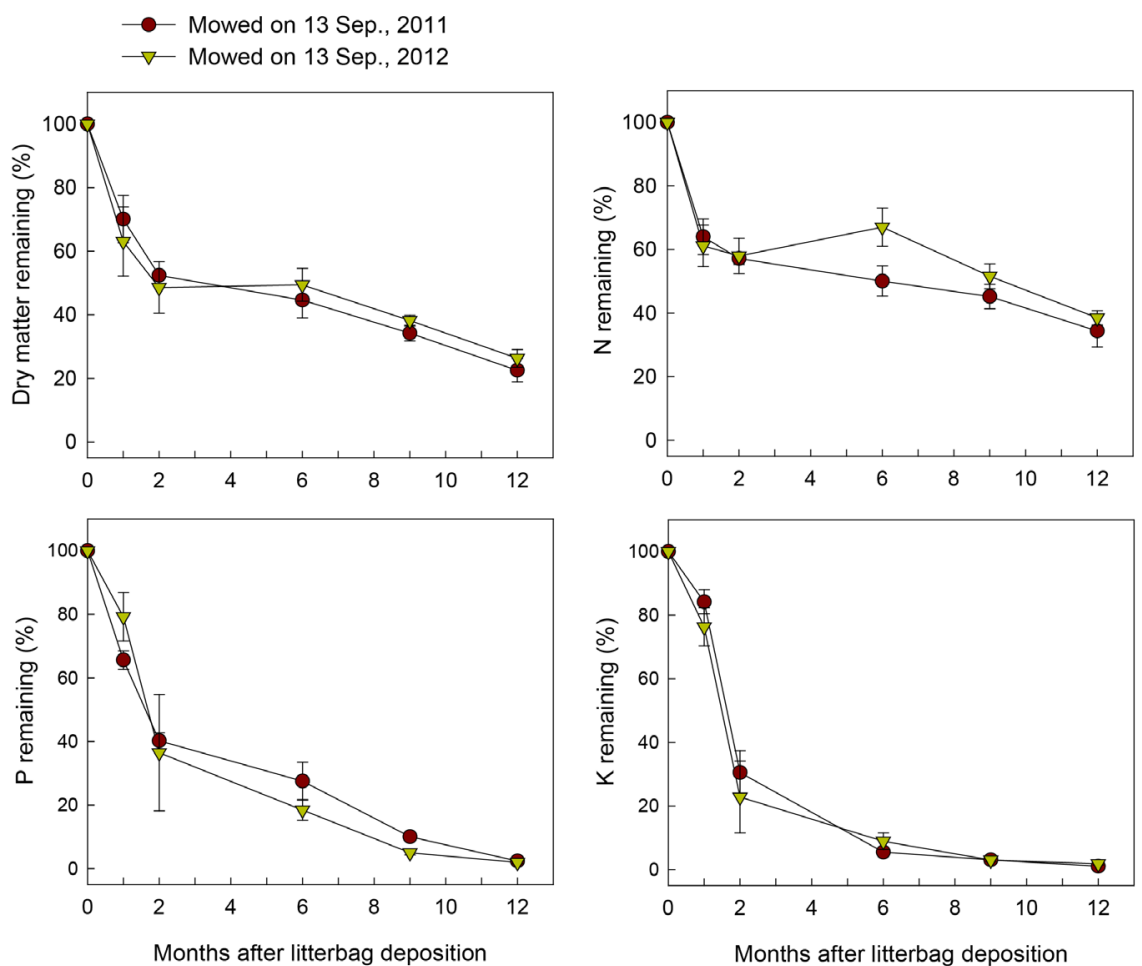

Figure 4. Dry matter (DM) and nutrient remaining (\% of initial content) in weed residues within litterbag deposited on the soil surface during the decomposition after mowing under tree canopy of a persimmon orchard on 13 September 2011 and 2012. Bars are standard error.

Although weed species were different, release of nutrients from the residues might be dependent on different mowing dates just as decomposition of DM. During the first month after deposition, the nutrients released the fastest in July weeds but the slowest in May weeds. These results indicated that the nutrient release is significantly promoted by higher temperature and rainfall condition due to fast decomposition and leaching [8] [15] [16]. Nutrient compositions and lignin and cellulose contents, and microorganisms could affect the releases [7] [8] [19].

Pattern of $\mathrm{N}$ release similar to the residue decomposition has been reported in the previous results [2] [20]. Therefore, $\mathrm{N}$ remaining decreased with more similar pattern to the DM than $\mathrm{P}$ and $\mathrm{K}$ remaining on different mowing dates. $\mathrm{N}$ release from the residues might be affected by chemical composition of weeds, since $\mathrm{N}$ release is negatively related to ratios of carbon to $\mathrm{N}$, polyphenol to $\mathrm{N}$, lignin to $\mathrm{N}$, and polyphenol plus lignin to $\mathrm{N}$ [11] [18] [21].

On the other hand, $\mathrm{P}$ and $\mathrm{K}$ releases from the residues did not follow the residue decomposition, as previously reported for organic substrates [22] [23]. Residual $\mathrm{P}$ and $\mathrm{K}$ decreased approximately by $100 \%$ until 10 months after litterbag deposition, much more than DM and N. Fast release of $\mathrm{P}$ in the initial stage of decomposition may come from soluble $\mathrm{P}$ in the residues and then from mineralization of organic $\mathrm{P}$ such as readily decomposable nucleic acids [24]. A previous 
study [25] also indicated that 40\% - 60\% of total P in grasses and legumes was present as inorganic $\mathrm{P}$ and rapidly released after incorporation of the residues into the soil. Thereafter little extra $\mathrm{P}$ might be continuously released from organic $\mathrm{P}$ compounds like phytin remaining [26].

It is not surprising that $\mathrm{K}$ release was faster than $\mathrm{N}$ and $\mathrm{P}$ for all mowing dates. This result reflected that $\mathrm{K}$ is not associated with structural components of plants, and it is normally found in the soluble form in the residues of cover plant [23] [27]. K release also depends less on microbiological decomposition of the residues, compared with $\mathrm{N}$ or P [27] [28] [29]. Thus, the extent of K release from September weeds is greater than $\mathrm{N}$ and $\mathrm{P}$, and the release continued even during Winter (Figure 4).

Decomposition process of the sod residues increases soil organic matter [30] and nutrient release in the sod residues imply an increase in minerals in the soil [29] [31]. Therefore, the nutrients, returned from the sod litter to soil, could directly determine the nutrient uptake of trees. Persimmon trees uptake mineral nutrients from the soil actively from Spring to Autumn [32] when weeds also vigorously grow. A total of $130 \mathrm{~kg} \mathrm{~N}$ and $100 \mathrm{~kg} \mathrm{~K}$ per ha is recommended as supplemental fertilizers for persimmon during the growing season in South Korea [32]. To clarify whether nutrients released from the weed residues could meet the demands for succeeding growth of persimmon trees, further research is necessary to determine total amount of nutrients in weeds mowed per unit land at different times. However, amount of the nutrient available to the tree may depend on how much of weeds grow again capturing nutrients from the weed residues after mowing.

Since excessive or deficient nutrient application at specific time can cause reduction of productivity or fruit quality of persimmon [33] [34]. The nutrients from the weed residues could significantly affect nutritional status of persimmon trees. If the nutrient release is too fast or slow to become available for the trees, its effect on tree development may be less than desired. Therefore, mowing and fertilization time should be considered as well as amount of nutrients released from the weed residues or fertilizers at the different times. Our results could help to adjust fertilization time after mowing weeds, and to decide appropriate mowing time to meet nutritional demand for the trees, under condition that newly growth of weeds subsequent to the mowing is suppressed during some period.

\section{Acknowledgements}

This research was supported in part by "Cooperative Research Program for Agricultural Science \& Technology Development” (Project PJ010189032016) of Rural Development Administration, Republic of Korea.

\section{References}

[1] Lim, K.H., Choi, H.S., Kim, W.S., Kim, S.G., Song, J.H., Cho, Y.S., Choi, J.J. and Jung, S.K. (2012) Nutrient Contribution of Green Manure Crops in an Organic Pear Orchard. Korean Journal of Organic Agriculture, 20, 37-48. 
[2] Jahanzad, E., Barker, A.V., Hashemi, M., Eaton, T., Sadeghpour, A. and Weis, S.A. (2016) Nitrogen Release Dynamics and Decomposition of Buried and Surface Cover Crop Residues. Agronomy Journal, 108, 1735-1741. https://doi.org/10.2134/agronj2016.01.0001

[3] Talgre, L., Lauringson, E., Roostalu, H. and Makke, A. (2014) Phosphorus and Potassium Release during Decomposition of Roots and Shoots of Green Manure Crops. Biological Agriculture and Horticulture, 30, 264-271. https://doi.org/10.1080/01448765.2014.953582

[4] Murungu, F.S., Chiduza, C., Muchaonyerwa, P. and Mnkeni, P.N.S. (2010) Decomposition, Nitrogen and Phosphorus Mineralization from Winter-grown Cover Crop Residues and Suitability for a Small Holder Farming System in South Africa. $\mathrm{Nu}$ trient Cycling in Agroecosystems, 89, 115-123.

https://doi.org/10.1007/s10705-010-9381-5

[5] Valenzuela-Solano, C. and Crohn, D.M. (2006) Are Decomposition and N Release from Organic Mulches Determined Mainly by Their Chemical Composition? Soil Biology and Biochemistry, 38, 377-384. https://doi.org/10.1016/j.soilbio.2005.06.002

[6] Ferreira, P.A.A., Girotto, E., Trentin, G., Miotto, A., Melo, G.W., Ceretta, C.A., Kaminski, J., Frari, B.K.D., Marchezan, C., Silva, L., Faversani, J.C. and Brunetto, G. (2014) Biomass Decomposition and Nutrient Release from Black Oat and Hairy Vetch Residues Deposited in a Vineyard. Revista Brasileira de Ciência do Solo, 38, 1621-1632. https://doi.org/10.1590/S0100-06832014000500027

[7] Matos, E.S., Mendonça, E.S., Cardoso, I.M., Lima, P.C. and Freese, D. (2011) Decomposition and Nutrient Release of Leguminous Plants in Coffee Agroforestry Systems. Revista Brasileira de Ciência do Solo, 35, 141-149. https://doi.org/10.1590/S0100-06832011000100013

[8] Trinsoutrot, I., Recous, S., Bentz, B., Lineres, D., Cheneby, D. and Nicolardot, B. (2000) Biochemical Quality of Crop Residues and Carbon and Nitrogen Mineralization Kinetics under Nonlimiting Nitrogen Conditions. Soil Science Society of America Journal, 64, 918-926. https://doi.org/10.2136/sssaj2000.643918x

[9] Seo, J.H., Lee, H.J., Kim, S.J., and Hur, I.B. (1998) Nitrogen Release from Hairy Vetch (Vicia villosa Roth) Residue in Relation to Different Tillages and Plant Growth Stage. Korean Journal of Soil Science and Fertilizer, 31, 137-142.

[10] Wilson, D.O. and Hargrove, W.L. (1986) Release of Nitrogen from Crimson Clover Residue under Two Tillage Systems. Soil Science Society of America Journal, 50, 1251-1254. https://doi.org/10.2136/sssaj1986.03615995005000050033x

[11] Lindsey, L.E., Steinke, K., Warncke, D.D. and Everman, W.J. (2013) Nitrogen Release from Weed Residue. Weed Science, 61, 334-340. https://doi.org/10.1614/WS-D-12-00090.1

[12] Lupwayi, N.Z., Clayton, G.W., O’Donovan, J.T., Harker, K.N., Turkington, T.K. and Rice, W.A. (2004) Decomposition of Crop Residues under Conventional and Zero Tillage. Canadian Journal of Soil Science, 84, 403-410. https://doi.org/10.4141/S03-082

[13] Nelson, D.W. and Sommers, L.E. (1973) Determination of Total Nitrogen in Plant Material. Agronomy Journal, 65, 109-112. https://doi.org/10.2134/agronj1973.00021962006500010033x

[14] National Institute of Agricultural Science and Technology (2000) Methods for Chemical Analysis of Soil and Plant. NIAST, Suwon.

[15] Agehara, S. and Warncke, D.D. (2005) Soil Moisture and Temperature Effects on Nitrogen Release from Organic Nitrogen Sources. Soil Science Society of America 
Journal, 69, 1844-1855. https://doi.org/10.2136/sssaj2004.0361

[16] Cabrera, M.L., Kissel, D.E. and Vigil, M.F. (2005) Nitrogen Mineralization from Organic Residues: Research Opportunities. Journal of Environmental Quality, 34, 75-79. https://doi.org/10.2134/jeq2005.0075

[17] Musvoto, C., Campbell, B.M. and Kirchmann, H. (2000) Decomposition and Nutrient Release from Mango and Miombo Woodland Litter in Zimbabwe. Soil Biology and Biochemistry, 32, 1111-1119.

[18] Baijukya, F.P., de Ridder, N. and Giller, K.E. (2006) Nitrogen Release from Decomposing Residues of Leguminous Cover Crops and Their Effect on Maize Yield on Depleted Soils of Bukoba District, Tanzania. Plant and Soil, 279, 77-93. https://doi.org/10.1007/s11104-005-2504-0

[19] Carvalho, J.L.N., Cerri, C.E.P., Feigl, B.J., Piccolo, M.C., Godinho, V.P. and Cerri, C.C. (2009) Carbon Sequestration in Agricultural Soils in the Cerrado Region of the Brazilian Amazon. Soil \& Tillage Research, 103, 342-349.

[20] Leblanc, H.A., Nygren, P. and McGraw, R.L. (2006) Green Mulch Decomposition and Nitrogen Release from Leaves of Two Inga spp. in an Organic Alley-Cropping Practice in the Humid Tropics. Soil Biology and Biochemistry, 38, 349-358.

[21] Palm, C.A. and Sanchez, P.A. (1991) Nitrogen Release from Some Leaves of Tropical Legume as Affected by Their Lignin and Polyphenolic Contents. Soil Biology and Biochemistry, 23, 83-88.

[22] Jalali, M. and Ranjbar, F. (2009) Rates of Decomposition and Phosphorus Release from Organic Residues Related to Residue Composition. Journal of Plant Nutrition and Soil Science, 172, 353-359. https://doi.org/10.1002/jpln.200800032

[23] Ranjbar, F. and Jalali, M. (2012) Calcium, Magnesium, Sodium, and Potassium Release during Decomposition of Some Organic Residues. Communications in Soil Science and Plant Analysis, 43, 645-659. https://doi.org/10.1080/00103624.2012.644005

[24] Ha, K.V., Marschner, P., Bunemann, E.K. and Smernik, R.J. (2007) Chemical Changes and Phosphorus Release during Decomposition of Pea Residues in Soil. Soil Biology and Biochemistry, 39, 2696-2699.

[25] Jones, O.L. and Bromfield, S.M. (1969) Phosphorus Changes during the Leaching and Decomposition of Hayed-off Pasture Plants. Australian Journal of Agricultural Research, 20, 653-663. https://doi.org/10.1071/AR9690653

[26] Lupwayi, N.Z., Clayton, G.W., O’Donovan, J.T., Harker, K.N., Turkington, T.K. and Soon, Y.K. (2007) Phosphorus Release during Decomposition of Crop Residues under Conventional and Zero Tillage. Soil \& Tillage Research, 95, 231-339.

[27] Marschner, H. (1995) Mineral Nutrition of Higher Plants. Academic Press Inc., San Diego, 299-312.

[28] Lupwayi, N.Z., Clayton, G.W., O'Donovan, J.T., Harker, K.N., Turkington, T.K. and Soon, Y.K. (2006) Soil Nutrient Stratification and Uptake by Wheat after Seven Years of Conventional and Zero Tillage in the Northern Grain Belt of Canada. Canadian Journal of Soil Science, 86, 767-778. https://doi.org/10.4141/S06-010

[29] Talgre, L., Lauringson, E., Roostalu, H., Astover, A. and Makke, A. (2012) Green Manure as a Nutrient Source for Succeeding Crops. Plant, Soil and Environment, 58, 275-281.

[30] Boehm, M.M. and Anderson, D.W. (1997) A Landscape-Scale Study of Soil Quality in Three Prairie Farming Systems. Soil Science Society of America Journal, 61, 1147-1159. https://doi.org/10.2136/sssaj1997.03615995006100040022x 
[31] Soon, Y.K. and Arshad, M.A. (2002) Comparison of the Decomposition and N and P Mineralization of Canola, Pea and Wheat Residues. Biology and Fertility of Soils, 36, 10-17. https://doi.org/10.1007/s00374-002-0518-9

[32] RDA (Rural Development Administration) (2013) Standard Agricultural Manual Persimmon Growing. RDA, Suwon, 132-137.

[33] Choi, S.T., Park, D.S., Cho, Y.C. and Kang, S.M. (2009) Tree Responses of "Fuyu" Persimmon to Urea Nitrogen Applied at Different Times during the Late Season. Acta Horticulturae, 833, 307-312. https://doi.org/10.17660/ActaHortic.2009.833.49

[34] Choi, S.T., Kang, S.M., Park, D.S., Hong, K.P. and Rho, C.W. (2011) Combined Effects of Leaf/Fruit Ratios and N and K Fertigation Levels on Growth and Distribution of Nutrients in Pot-grown Persimmon Trees. Scientia Horticulturae, 128, 364-368. 